Endocrinol. Japon. 1961, 8 (1), 50 56

\title{
STUDIES OF COLD TOLERANCE*
}

\author{
TOHRU AZUMA
}

\section{Second Clinic of Internal Medicine, School of Medicine, Hokkaido University, Sapporo}

The majority of studies on the regulation of body temperature in the process of acclimatization to the environmental temperature have assumed the following 2 mechanism: 1) Physical regulation; mainly to reduce the heat loss from the body surface, i.e. perspiration, dilatation or contraction of the skin vessels, etc., and 2) chemical regulation; to control the heat production in the body, in which the endocrine system is involved.

Torii has reported the increased urinary excretion of $17-\mathrm{KS}$ in winter and the increase of eosinopenic index after intravenous ACTH (Torii, 1953). In addition, the increased $\mathrm{BMR}$ and $\mathrm{PBI}$ in winter have been reported by Yoshimura (1956). It is obvious, therefore, that the cold tolerance in man is related with the endocrine functions, especially with the adenohypophysis, adrenal cortex, and thyroid.

In animal, reports on survival time in cold environment have indicated that thyroidectomy and adrenalectomy decreased while thyroxine increased the survival time of thyroidectomized rats (Zarrow and Money, 1949; Sellers and You, 1950; Heroux, 1954 ; Saunders, 1956).

The present studies are concerned with the effects of various hormone preparations and autonomic nerve blocking agents on the survival time of mice in a low ambient temperature in pursuit of the mechanism of acquisition of cold tolerance.

\section{MATERIALS AND METHODS}

Mature mice of the dd-strain weighing about $20 \mathrm{~g}$ were used. Exclusively male mice were used except in experiments using gonadal hormones.

For acclimatization to cold, the animals were kept in a cold room maintained at $-5 \pm 1^{\circ} \mathrm{C}$ for $1 \sim 3$ weeks. The control animals were kept at $25 \sim 30^{\circ} \mathrm{C}$ for the same period.

As a cold tolerance test, average survival time was determined when all animals were suddenly exposed to a extremely cold temperature of $-30 \sim-35^{\circ} \mathrm{C}$. Each group of 7 to 8 mice was checked for survival at 10 mins. interval.

Effects of castration on the survival time were also studied in relation to the gonadal hormones.

The effects of various preparations and treatments were all statistically analyzed in comparison with the results of control experiments.

\section{RESULTS}

A) The time required for acclimatization to cold

The average survival time of the group kept in a low ambient temperature

Received for publication November 30, 1960.

* These studies have been carried out with the assistance of the Grant in Aid for Scientific Research-Co-operate Research from the Ministry of Education. 
is obviously longer than the control group kept in a room temperature as indicated in Table 1. The time required for acclimatization to cold was at least 1 week. In addition, the group kept in the same condition for 3 weeks showed longer survival time than the group kept for 1 week.

It has been shown in another experiment that the time required for disappearance of the acquired cold acclimatization is approximately 1 week as indicated in Table 2.

Table 1. Time required for acclimatization to cold

\begin{tabular}{cccc} 
Survival time of mice kept at $-5 \pm 1{ }^{\circ} \mathrm{C}$ when exposed to the cold at $-30^{\circ} \mathrm{C}$ \\
\hline \multicolumn{2}{c}{ Treatment } & $\begin{array}{c}\text { No. of } \\
\text { mice }\end{array}$ & $\begin{array}{c}\text { Average survival time at } \\
-30^{\circ} \mathrm{C} \text { (mins.) }\end{array}$ \\
\hline 1) Kept at room temp. & 7 & 61.4 \\
2) Kept at $-5 \pm 11^{\circ} \mathrm{C}$ for 1 week & 7 & $81.4^{* *}$ \\
& for 3 weeks & 5 & $124.0 * *$ \\
\hline
\end{tabular}

** $: \mathrm{P}<0.01$

Table 2. Time required for disappearance of the acquired cold acclimatization

\begin{tabular}{cccc}
\hline & Treatment & $\begin{array}{c}\text { No. of } \\
\text { mice }\end{array}$ & $\begin{array}{c}\text { Average survival time at } \\
-30^{\circ} \mathrm{C} \text { (mins.) }\end{array}$ \\
\hline 1) Kept at room temp. $25^{\circ} \sim 30^{\circ} \mathrm{C}$ & 7 & 83.3 \\
2) Kept at $-5 \pm 11^{\circ} \mathrm{C}$ for 1 week & 9 & $200.0^{* *}$ \\
31 After 2) kept at room temp. & 9 & $168.8^{* *}$ \\
for 2 days & 9 & $140.0^{* *}$ \\
for 4 days & 8 & 91.3 \\
for 6 days & 8 & 95.0 \\
for 8 days & &
\end{tabular}

B) Direct effects of various preparations on the survival time

To demonstrate the direct effect of various preparations on the survival time of mice in the extreme cold, test preparations were given subcutaneously on the preceding day as well as immediately before exposure to the cold. Table 3 showed the results of the experiments. Prednisolone and thyroxine increased the survival time of the room temperature groups, thyroxine and chloropromazine increased the survival time of the cold acclimatized group; whereas DOCA, methylmercaptoimidazole and reserpin showed no effect.

C) The effects of various preparations on the process of acclimatization to cold

The effects were shown by treatment with a preparation every day from the beginning of acclimatization until 3 days prior to exposure to the extreme cold. The amount administered were the same as in the experiments B. The group acclimatized for 1 week was treated with a preparation for 5 successive days and the group acclimatized for 3 weeks for 19 successive days. 
Table 3. Direct effect of the various preparations on cold tolerance

Survival time of mice kept at $-5 \pm 11^{\circ} \mathrm{C}$ for 1 week when exposed to the cold at $-30 \sim-35^{\circ} \mathrm{C}$

\begin{tabular}{|c|c|c|c|c|c|}
\hline & \multirow{2}{*}{$\begin{array}{c}\text { Dose } \\
\mu \mathrm{g} / \text { mouse/day }\end{array}$} & \multicolumn{2}{|c|}{ No. of mice } & \multicolumn{2}{|c|}{ Average survival time (mins.) } \\
\hline$\mu \mathrm{g} / \mathrm{m}$ & & $\begin{array}{c}\text { Room temp. } \\
\text { group }\end{array}$ & Cold group & $\begin{array}{c}\text { Room temp. } \\
\text { group }\end{array}$ & Cold group \\
\hline \multicolumn{2}{|l|}{ No treatment } & 6 & 7 & 63.3 & 81.4 \\
\hline Prednisolone & 10 & 7 & 7 & $85.5^{* *}$ & 98.3 \\
\hline \multicolumn{2}{|l|}{ DOCA } & 5 & 6 & 64.0 & 85.0 \\
\hline \multicolumn{2}{|l|}{ Thyroxine } & 6 & 5 & $88.3^{* *}$ & $126.0 * *$ \\
\hline \multicolumn{2}{|c|}{ Methylmercaptoimidazo!e 10} & 6 & 7 & 75.0 & 84.3 \\
\hline \multicolumn{2}{|l|}{ Chloropromazıne } & 5 & 5 & 76.0 & $143.3^{* *}$ \\
\hline \multicolumn{2}{|l|}{ No treatment } & 9 & & 52.2 & \\
\hline Reserpin & 1 & 9 & & 60.0 & \\
\hline
\end{tabular}

Table 4. Effects of various preparations on the process of acclimatization to cold

Survival time of mice kept at $-5 \pm 1{ }^{\circ} \mathrm{C}$ for 3 weeks, in the studies of DOCA and reserpin for 1 week, when exposed to the cold at $-30^{\circ} \mathrm{C}$

\begin{tabular}{|c|c|c|c|c|c|}
\hline & \multirow{2}{*}{$\begin{array}{c}\text { Dose } \\
\mu \mathrm{g} / \text { mouse/day }\end{array}$} & \multicolumn{2}{|c|}{ No. of mice } & \multicolumn{2}{|c|}{ Average survival time (mins.) } \\
\hline & & 1st exp. & 2nd exp. & 1st exp. & 2nd exp. \\
\hline No treatment & & 5 & 9 & 130.0 & 221.1 \\
\hline Prednisolone & 10 & 6 & 6 & $90.0 * *$ & $125.3^{* *}$ \\
\hline Thyroxine & 10 & 7 & & $180.0 * *$ & \\
\hline \multirow[t]{3}{*}{ Methylmercaptoimidazole } & 10 & & 9 & & $162.2^{* *}$ \\
\hline & 20 & & 5 & & $146.0 *$ \\
\hline & 50 & & 9 & & $154.4^{* *}$ \\
\hline Chloropromazine & 10 & & & 102.0 & \\
\hline No treatment & & 10 & & 103.0 & \\
\hline DOCA & 5 & 10 & & 109.0 & \\
\hline No treatment & & 9 & & 115.5 & \\
\hline Reserpin & 1 & 9 & & $84.4^{*}$ & \\
\hline
\end{tabular}

As Table 4 indicates, the animals treated with prednisolone, methylmercaptoimidazole, and reserpin during acclimatization to the cold showed shorter survival time by exposure to the extreme cold, indicating a decrease in the ability of acclimatization to cold temperature; whereas thyroxine increased both cold acclimatization and cold tolerance. DOCA and chloropromazine were without effect. D) Sexual difference in the survival time of the cold acclimatized mice

Comparison of the survival time of male and female mice showed a longer survival in the male as indicated in Table 5. 
Table 5. Sexual difference in the cold tolerance

The survival time of mice kept at $-5 \pm 11^{\circ} \mathrm{C}$ for 1 week when exposed to the cold at $-30^{\circ} \sim-35^{\circ} \mathrm{C}$

\begin{tabular}{llccccc}
\hline \hline & \multirow{2}{*}{ Sex } & \multicolumn{3}{c}{ No. of mice } & & \multicolumn{2}{c}{ Average survival time (mins.) } \\
& & 1st exp. & 2nd exp. & & 1st exp. & 2nd exp. \\
\hline Room temp. & male & 9 & 13 & & 52.2 & 56.9 \\
group & female & 7 & 15 & & 52.8 & $37.3^{* *}$ \\
\hline Cold acclim. & male & 9 & 15 & & 115.3 & 106.0 \\
group & female & 9 & 13 & & $67.7^{* *}$ & 87.7 \\
\hline$* *: P<0.01$ & & & & & &
\end{tabular}

Table 6. Effect of castration on the male mice

The survival time of mice kept at $-5 \pm 1^{\circ} \mathrm{C}$ for 1 week when exposed to the cold at $-30 \sim-35^{\circ} \mathrm{C}$

\begin{tabular}{lcccccc}
\hline \hline \multirow{2}{*}{ Treatment } & \multicolumn{2}{c}{ No. of mice } & & \multicolumn{2}{c}{ Average survival time (mins.) } \\
\cline { 2 - 3 } & 1st exp. & 2nd exp. & & 1st exp. & 2nd exp. \\
\hline Sham-operated & 9 & 8 & & 76.6 & 101.3 \\
Castrated & 10 & 9 & & $156.0 * *$ & 101.0 \\
\hline$* *: P<0.01$ & & & & & &
\end{tabular}

Table 7. Effect of castration on the female mice

The survival time of mice kept at $-5 \pm 11^{\circ} \mathrm{C}$ for 1 week when exposed to the cold at $-30 \sim-35^{\circ} \mathrm{C}$

\begin{tabular}{lcccccc}
\hline \multirow{2}{*}{ Treatment } & \multicolumn{3}{c}{ No. of mice } & & \multicolumn{2}{c}{ Average survival time (mins.) } \\
\cline { 2 - 3 } \cline { 6 - 7 } & 1st exp. & 2nd exp. & & 1st exp. & 2nd exp. \\
\hline Sham-operated & 9 & 7 & & 41.1 & 82.9 \\
Castrated & 8 & 9 & & $78.7^{* *}$ & $113.3^{* *}$ \\
\hline
\end{tabular}

$* *: P<0.01$

\section{E) The effects of castration}

Each 2 groups of both sexes were castrated. Two weeks after the castration the mice were kept in a low ambient temperature for 1 week. The sham-operated groups were treated similarly as the controls. As shown in Tables 6 and 7, increases of the survival time were observed in the castrated mice of both sexes.

F) The effects of gonadal hormones

The castrated groups of both sexes were treated with androgen or estrogen in the process of acclimatization as in experiment C. It is obvious from the result indicated in Tables 8 and 9 that androgen had no effect while estrogen enhanced the acclimatization to cold in the castrated mice of both sexes. 
Table 8. The effect of testosterone propionate (T.P.) on the castrated mice

The survival time of mice kept $\mathrm{a}_{\mathrm{i}}^{2}-5 \pm 1^{\circ} \mathrm{C}$ for 1 week when exposed to the cold at

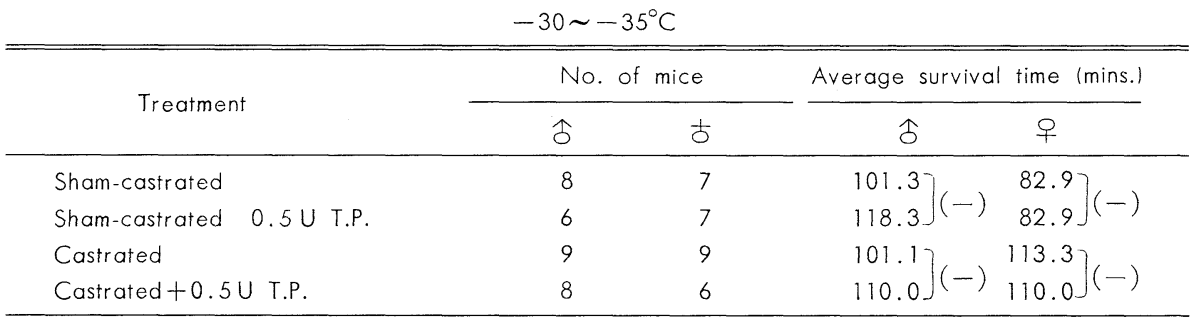

Table 9. The effect of estradiol benzoate (E.B.) on the castrated mice

The survival time of mice kept at $-5 \pm 1^{\circ} \mathrm{C}$ for 1 week when exposed to the cold at $-30^{\circ} \sim 35^{\circ} \mathrm{C}$

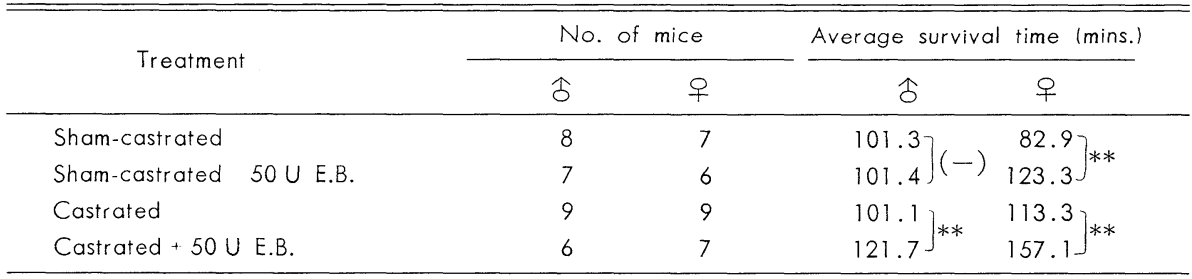

** $: P<0.01$

\section{DISGUSSION}

One week was necessary for both acquisition and withdrawal of acclimatization to cold. It is obvious, therefore, that biological mechanism to withstand the cold temperature develops gradually and is reversible, in which endocrine system may play a leading role.

The summary of effects of hormones is shown in Table 10. Thyroid hormone increased both the cold tolerance and cold acclimatization, whereas antithyroidal drug exerted an inhibitory action on cold acclimatization. From this experiment and the observations in man (Yoshimura, 1956) it is conceivable that the thyroid gland physiologically increases its activity in producing heat as to tolerate cold environment.

Furthermore, it should also be remembered that glucocorticoids play one of the important roles in the heat production to withstand to cold (Horvath, 1938; Ring, 1938), and are necessary in the calorigenic action of thyroid hormone (Engel, 1953; Fukuda, 1957). The inhibitory action of prednisolone in the process of acclimatization is probably attributed to the adrenal insufficiency after steroid withdrawal. It is unlikely from the data with DOGA that mineralcorticoid participates in the mechanism of acclimatization.

Chloropromazine increased directly the cold tolerance of mice. It may be 
Table 10. Summary of the effect of the preparations examined

\begin{tabular}{|c|c|c|c|}
\hline \multirow{2}{*}{ Treatment } & \multicolumn{2}{|c|}{ Direct effect } & \multirow{2}{*}{$\begin{array}{c}\text { Effect on the process } \\
\text { of } \\
\text { cold acclimatization }\end{array}$} \\
\hline & $\begin{array}{l}\text { Room temp. } \\
\text { group }\end{array}$ & $\begin{array}{l}\text { Cold acclim. } \\
\text { group }\end{array}$ & \\
\hline Prednisolone & $\uparrow$ & - & $\downarrow$ \\
\hline DOCA & - & 一 & 一 \\
\hline Thyroxine & $\uparrow$ & $\uparrow$ & $\uparrow$ \\
\hline Methylmercaptoimidazole & - & - & $\downarrow$ \\
\hline Chloropromazine & - & $\uparrow$ & \\
\hline Reserpin & - & & \\
\hline Testosterone propionate $\left\{\begin{array}{l}\hat{\delta} \\
\text { 우 }\end{array}\right.$ & $\overline{\hat{i}}$ & & - \\
\hline Estradiol benzoate $\left\{\begin{array}{l}\hat{\delta} \\
\text { 우 }\end{array}\right.$ & $\bar{\uparrow}$ & - & $\uparrow$ \\
\hline $\begin{array}{l}\uparrow: \text { increase the survival time of mice } \\
\downarrow \text {. decrease the survival time of mice }\} \\
\uparrow: \text { increase the survival time of mice * } \\
-: \text { without effect } \\
*: P<0.05 \\
* *: P<0.01\end{array}$ & & & \\
\hline
\end{tabular}

due to the alleviation of various disturbances following exposure to the extreme cold.

The mechanism of castration in increasing the survival time of mice remains obscure.

Contrary to the report presented by Zarrow and Denison (1956), the survival time of the male mice was longer than the female. The discrepancy may be attributed to species difference. The effect of gonadal hormones on normal mice was variable; whereas on the castrated animals androgen had no effect and estrogen effected an increased tolerance to cold.

Though gonadal hormones may not be necessary for the resistance to cold, they may indirectly influence the mechanism of cold tolerance through the thyroid, adrenal cortex, or other organs.

\section{SUMMARY}

Mature mice, acclimatized in a low ambient temperature at $-5 \pm 1^{\circ} \mathrm{C}$, were exposed to the extreme cold at $-30 \sim-35^{\circ} \mathrm{C}$ and the survival time was determined. The mice were treated with various preparations during acclimatization or immediately before the exposure.

The results obtained are as follows: 1) The time required for acquisition and disappearance of acclimatization to cold was less than 1 week. 2) Prednisolone increased the survival time of mice when treated before exposure, while it decreased the cold tolerance probably due to adrenal suppression when treated during acclimatization. 3) DOGA was without effect. 4) Thyroxine increased the survival time regardless of the time of medication, whereas methylmercapto- 
imidazole decreased it when treated during acclimatization. 5) Chloropromazine increased the cold tolerance directly, while reserpin was without effect. 6) Castration appeared to increase the cold tolerance. 7) The survival time of the male mice was longer than the female. 8) Androgen was without effect, while estrogen increased the cold tolerance when treated during acclimatization of the castrated mice of both sexes.

\section{ACKNOWLEDGEMENT}

Grateful acknowledgement is made to Prof. T. Torii for his advice. criticism and stimulus in this studies.

\section{REFERENCES}

Engel, F. L. (1953). J. Clin. Endocrinol. and Metabolism 13, 1555.

Fukuda, A. The Abstract of the 2nd Conference of Cold Physiology in January, 1957. (In Japanese)

Heroux, O. and J. S. Hart (1954). Am. J. Physiol. 178, 449.

Horvath, S. M., F.A. Hitchcock and F.A. Hartman (1938). Ibid. 121, 178.

Ring, G. C. (1938). Jbid. 122, 435.

Saunders, E. J. (1956). Endocrinology 58, 412.

Sellers, E. A. and S. S. You (1950). Am. J. Physiol. 163, 81.

Torii, T. (1953). The Saishin-Igaku 8, 999. (In Japanese)

Yoshimura, F. The Abstract of the 1st Conference of Cold Physiology in September, 1956. (In Japanese)

Zarrow, M. X. and W. L. Money (1949). Endocrinology 44, 345.

Zarrow, M. X. and M. E. Denison (1956). Am. J. Physiol. 186, 216. 